\title{
Effects of the Hybridization of Opioid and Neurotensin Pharmacophores on Cell Survival in Rat Organotypic Hippocampal Slice Cultures
}

\author{
Patrycja Kleczkowska ${ }^{1,2} \cdot$ Maria Kawalec ${ }^{3} \cdot$ Magdalena Bujalska-Zadrozny $^{2}$ • \\ Małgorzata Filip $^{4,5} \cdot$ Barbara Zablocka $^{3} \cdot$ Andrzej W. Lipkowski $^{1}$
}

Received: 17 April 2015/Revised: 4 August 2015/Accepted: 4 August 2015/Published online: 19 August 2015

(C) The Author(s) 2015. This article is published with open access at Springerlink.com

\begin{abstract}
Several neurotransmitter and neuromodulatory systems can control physiological glutamatergic activity. For example, opioid receptor ligands were shown to partially inhibit $N$-methyl-D-aspartic acid (NMDA) receptordependent glutamatergic excitotoxicity. Also, the endogenous tridecapeptide neurotensin (NT) was found to modulate excessive glutamate release and glutamate receptor activity in neurons. Alternatively to the one target-one drug approach, it has been well documented that hybrid compounds encompassing two pharmacophores in one molecular scaffold can represent more potent drugs. Moreover, such structures with dual activity can potentially enable a reduction of undesirable side effects and/or
\end{abstract}

Patrycja Kleczkowska and Maria Kawalec have contributed equally to the work.

Andrzej W. Lipkowski-deceased.

Patrycja Kleczkowska

hazufiel@wp.pl

1 Department of Neuropeptides, Mossakowski Medical Research Centre, Polish Academy of Sciences, 5 Pawinskiego Str., 02-106 Warsaw, Poland

2 Department of Pharmacodynamics, Centre for Preclinical Research and Technology, CEPT, Medical University of Warsaw, 1B Banacha Str., 02-106 Warsaw, Poland

3 Molecular Biology Unit, Mossakowski Medical Research Centre, Polish Academy of Sciences, 5 Pawinskiego Str., 02-106 Warsaw, Poland

4 Department of Toxicology, Faculty of Pharmacy, Jagiellonian University, College of Medicum, 9 Medyczna Str., 30-688 Kraków, Poland

5 Laboratory of Drug Addiction Pharmacology, Department of Pharmacology, Institute of Pharmacology, Polish Academy of Sciences, 12 Smętna Str., 31-343 Kraków, Poland improved bioavailability. Herein, we describe the neuroprotective potential of an opioid-NT hybrid peptide (PK20), which was recently designed and synthesized within our group. The protective properties of PK20, assessed in an in vitro model of excitotoxic injury in organotypic hippocampal slice cultures subjected to NMDA, were compared to the effects caused by NT. Our results indicate that PK20 is a potent anti-neurodegenerative agent. Moreover, co-administered with NMDA, PK20 $(25-100 \mathrm{ng} / \mathrm{ml})$ dose-dependently reduced hippocampal cell death, determined by a decrease in the propidium iodide signal. We also report for the first time the significant NT-induced neuroprotective effect, as its application $(50-100 \mathrm{ng} / \mathrm{ml})$ to hippocampal slice cultures protected CA1 damage against neurotoxicity caused by NMDA.

Keywords Hippocampus $\cdot$ Hybrid peptide $\cdot$ Neurotensin . Opioid · Neurotoxicity

$\begin{array}{ll}\text { Abbreviations } \\ \text { CNS } & \text { Central nervous system } \\ \text { DIV } & \text { Day in vitro } \\ \text { NMDA } & N \text {-methyl-D-aspartic acid } \\ \text { NT } & \text { Neurotensin } \\ \text { PI } & \text { Propidium iodide }\end{array}$

\section{Introduction}

Glutamate, being the main excitatory neurotransmitter in the brain, is responsible for neurodegeneration and neuronal damage (Arundine and Tymianski 2004; Hynd et al. 2004; Olney et al. 1972). In fact, glutamate's prolonged and excessive release causes over-stimulation of its 
receptors, especially the $N$-methyl-D-aspartic acid (NMDA) receptors, which consequently leads to excitotoxicity (Mark et al. 2001). This pathological process, by which neurons are damaged, is well-established and is well-observed in, for example hippocampal pyramidal cells (CA1 region), which are known to be one of the most sensitive to excitotoxicity. At the present time, organotypic hippocampal slice culture analysis is one of the powerful experimental approaches to examine mechanisms of neuronal injury, in which the basic architecture and composition of the hippocampus is relatively preserved (Murphy et al. 2008; Noraberg et al. 2005; Ring et al. 2010). Hippocampal slice cultures exposed to NMDA or oxygen and glucose deprivation (OGD) are being used for screening the neuroprotective effects of new potent drugs.

By use of the hippocampal slice/NMDA model, previous studies have shown that opioid ligands, including morphine and the peptide biphalin, express neuroprotective properties (Liu et al. 2008; Kawalec et al. 2011). Interestingly, both morphine and biphalin express a ceiling protective effect that was proposed to be directly related to the proportion of cells containing particular neuropeptide receptor types on their membranes. While biphalin - with a good affinity for mu-, delta-, and kappa opioid receptors-expressed protection in as much as $65 \%$ of the cells, mu receptor selective ligands expressed a ceiling protective effect up to $50 \%$ (Kawalec et al. 2011). Therefore, we hypothesized that the activation of other neuropeptide receptors may result in independent protection and may result in additive or synergic effects when applied together with opioids.

This paper reports on the neuroprotective properties of neurotensin (NT) and a peptide chimera that consists of covalently linked NT and opioid pharmacophores. The combination of these two elements were chosen since (i) the brain's opioidergic system plays an important role not only in antinociceptive mechanisms but also in the pathophysiology of neurodegenerative disorders (e.g., transient ischemia-induced delayed neuronal cell death) (Narita et al. 2006; Vaccarino et al. 1999); (ii) kappa and/or delta opioid receptor agonists exhibit neuroprotection by decreasing presynaptic release of glutamate in vitro (Bradfrod et al. 1986; Chen et al. 2004; Pinnock 1992; Zhang et al. 2000) or attenuate glutamate-dependent oxidative damage (Yang et al. 2009); (iii) neurochemical and biochemical data indicate that NT plays a crucial role in the regulation of glutamatergic transmission (Antonelli et al. 2004). However, little is known about NT's role on neurons survival. Moreover, the physiological distribution of naturally existing opioid and NT in the hippocampus area has been reported (Köhler et al.1987; Li and Lei 2006).

Altogether, these data prompted us to synthesize a novel drug type against the NMDA receptor-dependent excitotoxicity. Such a new drug, called chimera, hybrid, or multi-/bi-functional drug, is believed to have many advantages including a high activity and stability to enzymatic degradation. Additionally, its chemical structure allows the modulation of pharmacokinetic properties and consequently, the creation of "site specificity of action" (Kleczkowska et al. 2013). A compound that contains an opioid and NT pharmacophores in one chemical structure is thought to entail a novel entity potentially characterized by much more stronger activity, compared to the properties of each element alone. Indeed, as presented here, PK20 is a novel hybrid peptide containing a modified endomorphin-2 (as an opioid pharmacophore, located on the N-terminus) and a modified fragment of NT(8-13), which constituted the C-terminal part of the presented chimera (Kleczkowska et al. 2010). The insertion of several unnatural amino acids (e.g., dimethyltyrosine, tertleucine) in the peptide chain resulted in an improved enzymatic stability, which additionally possesses high antinociceptive potency and the ability to cross the blood-brain barrier. Apart from PK20, in the present study, we assumed that the opioid part can effectively modulate the behavior of the NT analog and can thus change its neuroprotective profile, since neurotensin and its analogs are found to favor degenerative effects induced by NMDA. This, in turn, may result from the putative ability of NT and opioid receptors to form a functionally interacting heteromeric complex.

Therefore, the aim of this study was to determine whether a chemical hybridization of both naturally existing peptides could influence the final profile of the compound in the context of its neuroprotective/neurodegenerative properties. Additionally, we would like to present neurotensin as a good protector against NMDA-induced excitotoxicity.

\section{Materials and Methods}

\section{Animals}

Animals were provided from the Animal House of Mossakowski Medical Research Centre Polish Academy of Sciences (Warsaw, Poland). The experiments were performed on male Wistar rats at postnatal days 6-7. Before the study, all animals were housed together with their mother rat in standard plastic cages lined with wood shavings. A 12/12 h light-dark cycle was kept with lights on at $0700 \mathrm{~h}$. The temperature was maintained at $22{ }^{\circ} \mathrm{C}$ and the relative humidity was in the range of 55-60\%. Food and water were freely available to the adult animals.

\section{Reagents}

Hank's balanced salt solution (HBSS), horse serum (HS), neurobasal, HEPES buffer, as well as antibiotic/ 
antimycotic solution (AAS), and B-27 supplement were purchased from Gibco (Poland). NMDA and propidium iodide (PI) were purchased from Sigma-Aldrich (Poland).

PK20 was synthesized previously by Kleczkowska, using Fmoc-strategy Solid Phase Peptide-Synthesis.

\section{Organotypic Hippocampal Slice Culture (OHC)}

Hippocampal slices were prepared from Wistar rats at postnatal days 6-7 according to the slightly adapted method described by Stoppini et al. (1991). In brief, icecooled pups were decapitated, and the brains were placed in ice-cold HBSS (Gibco) for further hippocampi isolation. The hippocampi were cut into $400-\mu \mathrm{m}$ slices using McIlwain tissue chopper and gently separated in a Petri dish. Best slices were transposed onto Millicell-CM (Millipore) membranes in a 6-well plate. Membranes were placed in medium (pH 7.2, $50 \%$ Neurobasal, $22 \%$ HBSS, $5 \mathrm{mg} / \mathrm{ml}$ glucose, $0.8 \%$ antibiotic/antimycotic solution, and $2.5 \%$ HEPES $1 \mathrm{M}$ ) supplemented with $25 \%$ HS, according to Gähwiler et al. (1997). Medium was replaced every 2-3 days. From the 3rd to 8th DIV, HS was gradually reduced by two-thirds (serum-depleted medium). Cultures were maintained in a moist atmosphere at $36{ }^{\circ} \mathrm{C}$ in $5 \%$ $\mathrm{CO}_{2}$.

All experimental procedures were approved by The Local Committee for Ethics in Animal Experiments (Permit Number: 14/2012).

\section{Induction of an Excitotoxic Stress and Peptide Treatment}

After 9 days in vitro, the excitotoxic injury was induced by the addition of $1 \mathrm{mM}$ NMDA for $3 \mathrm{~h}$. Then the slices were transferred to the fresh culture medium. NT (50 and $100 \mathrm{ng} / \mathrm{ml})$, PK20 (25, 50 and $100 \mathrm{ng} / \mathrm{ml})$ were applied alone or together with NMDA, and were present throughout the experiment up to $24 \mathrm{~h}$.

Additionally, selective antagonists of opioid (naltrexone) or NT (SR48692) receptors at concentrations of 50 and $100 \mathrm{ng} / \mathrm{ml}$, were applied together with NMDA and with an unchangeable dose of PK20 (50 ng/ml).

\section{Analysis of Cell Death}

After $24 \mathrm{~h}$, a fluorescent death marker, PI $(4.5 \mu \mathrm{M})$, was added to each well. Following 30-min exposure, photographs were taken using a LSM780 laser-scanning microscope (Zeiss, Germany). To quantify the injury induced by either NMDA or the tested drugs, PI fluorescence intensity in the CA1 region (marked on the $1 \mathrm{mM}$ NMDA picture of Figs. 2a and 3a) was analyzed using a custom-made program, and the following formula:
$\%$ of dead cells $=$ experimental fluorescent intensity $(\mathrm{FI}) /$ maximal FI $\times 100$, where maximal FI is obtained by applying $10 \mathrm{mM}$ NMDA.

In the present experiments, NMDA concentrations increased up to $10 \mathrm{mM}$, despite the commonly used concentration to induce excitotoxicity $(0.1 \mathrm{mM})$ and maximally applied one $(1 \mathrm{mM})$. Our experiments showed that commonly used NMDA concentrations in the presence of serum (even depleted) did not induce damage.

\section{Statistical Analysis}

Data are expressed as the mean \pm S.D. of at least six independent experiments (at least four slices in each combination, each experiment). The statistical significance was determined by one-way ANOVA followed by Bonferroni test for simultaneous analysis of multiple test groups. The criterion for statistical relevance was established at $P<0.05, P<0.001$, or $P<0.0001$. Statistical analysis was performed with the GraphPad Prism software version 5.0 (GraphPad Software Inc., San Diego, CA, USA).

\section{Results}

The number of dead cells labeled with PI was counted in order to assess the effects of NT and PK20 (structures shown in Fig. 1) on NMDA-induced cell death.

In our model, NT (50-100 ng/ml) alone did not affect the CA1 region at any concentration (Fig. 2). The percentage of PI-positive cells was $2.5 \% \pm 1.62$ for $50 \mathrm{ng} / \mathrm{ml}$ NT and $1.15 \% \pm 0.63$ for $100 \mathrm{ng} / \mathrm{ml} \mathrm{NT}$, and no significant difference compared to the control was observed, where cell death always occurs spontaneously on a small scale (i.e., $1.28 \% \pm 0.99$ ).

Challenge of slices with $1 \mathrm{mM}$ NMDA for $3 \mathrm{~h}$ caused cell damage in the CA1 region, which in our model corresponded to $33.6 \% \pm 13$. However, when NT was applied together with NMDA, the percentage of PI-positive cells decreased to $9.57 \% \pm 4.07$ at an applied concentration of $50 \mathrm{ng} / \mathrm{ml} \mathrm{NT}$ and $4.67 \% \pm 2.41$ of $100 \mathrm{ng} / \mathrm{ml}$ NT. These values were significantly lower than the one for NMDA alone (Fig. 2).

To examine the effects of PK20 on neuronal survival, we used three different concentrations $(25,50$, and $100 \mathrm{ng} /$ $\mathrm{ml}$ ) of the compound. Our data showed that hippocampal slices cultured for $24 \mathrm{~h}$ with this novel hybrid peptide were almost undamaged at the lowest dose of $25 \mathrm{ng} / \mathrm{ml}$, at which almost no cell death was detected $(1.47 \% \pm 1.2)$ (Fig. 3). However, at higher concentrations PK20 slightly increased cell damage in the CA1 region, and the percentage of PI- 
Fig. 1 Representative structures of examined compounds. a Neurotensin; b PK20 opioid-neurotensin hybrid peptide

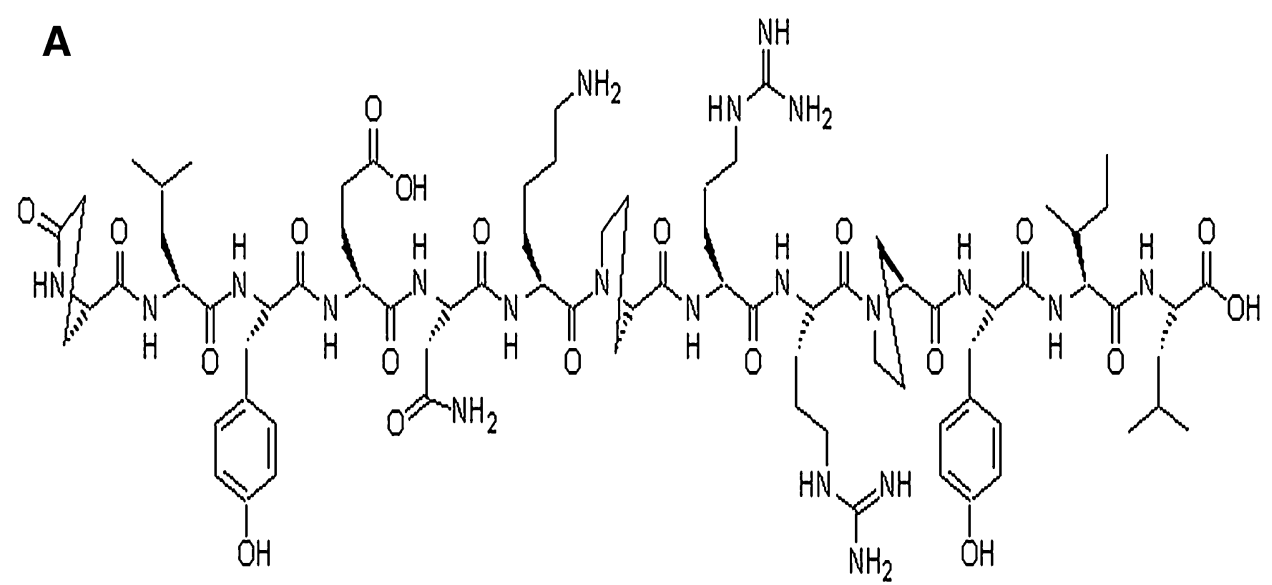

B positive cells for 50 and $100 \mathrm{ng} / \mathrm{ml}$ of PK20 was $5.18 \% \pm 2.84$ and $6.82 \% \pm 6.08$, respectively. Importantly, only the highest PK20 concentration resulted in a value statistically different $(P<0.001)$ from untreated control slices.

Co-administration of PK20 with NMDA significantly decreased the percentage of PI-positive cells in the CA1 region compared to NMDA alone; $25 \mathrm{ng} / \mathrm{ml}$ PK20 reduced cell damage to $13.01 \% \pm 8.68$, representing almost $50 \%$ reduction in PI-positive cells. Higher concentrations of PK20, $50 \mathrm{ng} / \mathrm{ml}$ and $100 \mathrm{ng} / \mathrm{ml}$, reduced NMDA-induced cell damage to $6.11 \% \pm 4.09$ and $5.92 \% \pm 3.79$, respectively, so that the percentage of PI-positive cells was almost comparable to untreated control. In fact, a statistical difference $(P<0.001)$ between PK20 $100+$ NMDA and untreated control slices was reported.

Additionally, the inhibition of opioid receptors by naltrexone or NTS1 receptors by SR 48692 in the presence of NMDA and PK20 $(50 \mathrm{ng} / \mathrm{ml})$ did not annihilate the neuroprotective effect of PK20 (Fig. 4).

\section{Discussion}

A growing number of studies on the development and determination of the neuroprotective potency of various drugs have been conducted over the past few years (Yang et al. 2011a, b). In the field of neurodegenerative disease treatment, there have also been a few articles describing the use of compounds containing at least two chemically connected drugs, known as hybrids, chimeras, designed multifunctional drugs or bi/multifunctional drugs. Chiba et al. (2007) recently presented Colivelin as a novel neuroprotective peptide that contains an activity-dependent neurotrophic factor (ADNF) pharmacophore and the N-terminus of a potent Humanin derivative, AGA-(C8R)HNG17. In addition, Kawalec et al. (2011) showed that a dimeric enkephalin, named biphalin, protects from NMDA-mediated excitotoxicity in organotypic hippocampal slice cultures derived from rats. However, to date, there are no data describing any of the peptides that contain both opioid and NT pharmacophores as compounds able to modulate NMDA-induced neuronal cell death. Herein, 
Fig. 2 Dose-dependent neuroprotective effect evoked by the administration of neurotensin in vitro in rat organotypic hippocampal cultures (OHC).

a Representative black and white inverted photos of hippocampal slices challenged with $1 \mathrm{mM}$ NMDA in the presence of neurotensin NT $(50$ and $100 \mathrm{ng} / \mathrm{ml}$ ) obtained $24 \mathrm{~h}$ after excitotoxic stress. Dead cells were visualized by propidium iodide staining. Polygon shows the area that was calculated on each slice. b Quantitative analysis of cell death of OHC, $24 \mathrm{~h}$ after glutamatergic stress. The results are expressed as the mean \pm S.D. of propidium iodide (PI) positive cells from at least three independent experiments. $* P<0.001$, $* * P<0.0001$ versus control; ${ }^{\# \#} P<0.0001$ versus NMDA
A
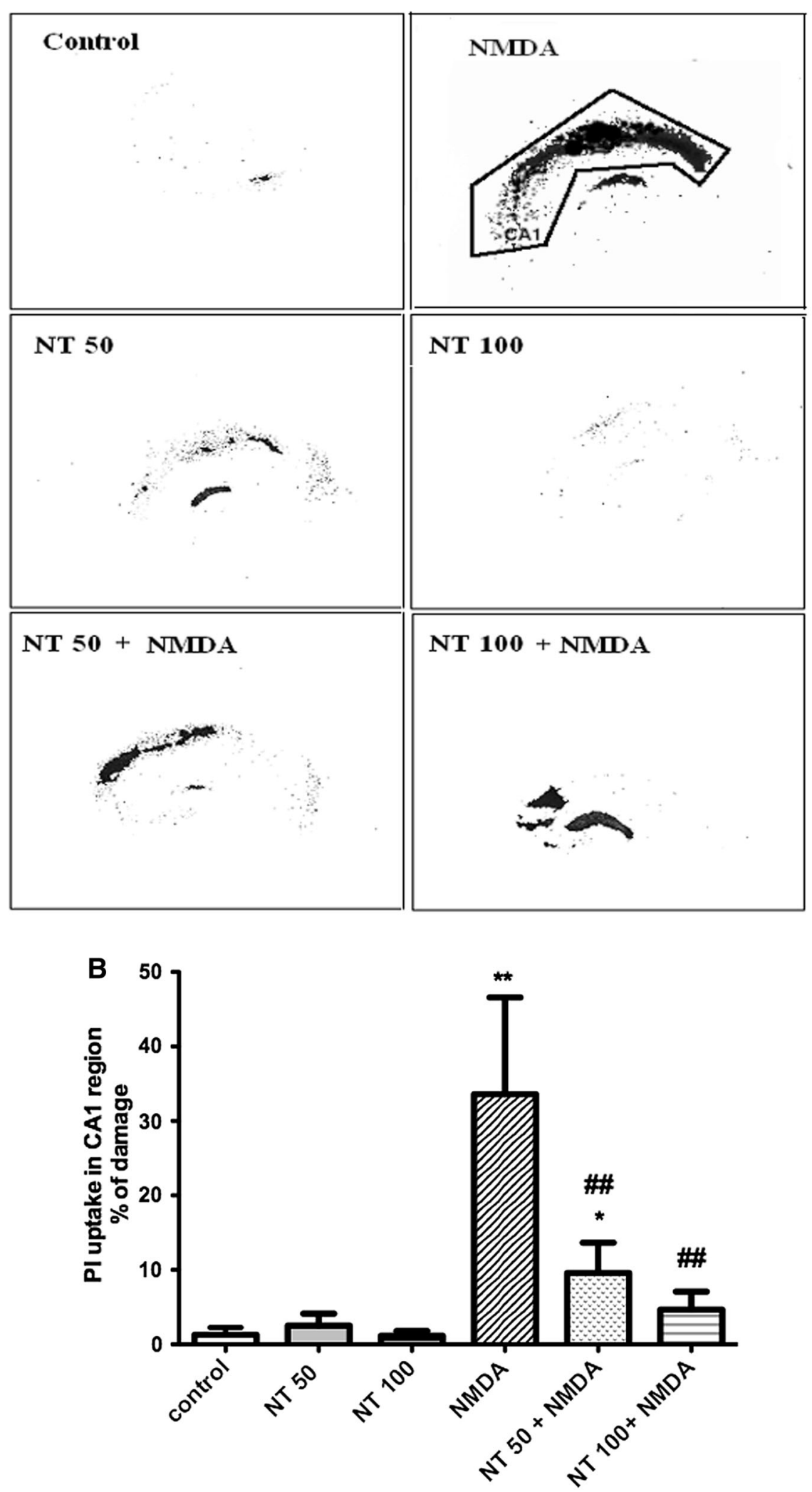

using NMDA-treated organotypic hippocampal slice cultures, we are the first to present the neuroprotective activity of PK20, an opioid-neurotensin hybrid.
Our data show that PK20 and the endogenous peptide NT do not affect the CA1 region of the rat hippocampus in organotypic slice cultures. Only the highest tested 
Fig. 3 Neuroprotective activity of PK20 opioid-neurotensin chimera in vitro in rat organotypic hippocampal cultures (OHC). a Inverted fluorescent images of propidium iodide-stained (PI) hippocampal slices $24 \mathrm{~h}$ after NMDAinduced glutamatergic stress. Damage was detected mostly in the CA1 area (defined by the line). PK20 in the different doses $(25-100 \mathrm{ng} / \mathrm{ml})$ administered either alone or was co-administered with NMDA $(1 \mathrm{mM})$. b Quantitative analysis of cell death of OHC, $24 \mathrm{~h}$ after glutamatergic stress $(1 \mathrm{mM}$ NMDA). The results are expressed as the mean \pm S.D. of PI-positive cells from at least three independent experiments. ${ }^{*} P<0.05,{ }^{*} * P<0.0001$ versus control; ${ }^{\# \#} P<0.0001$ versus NMDA
A
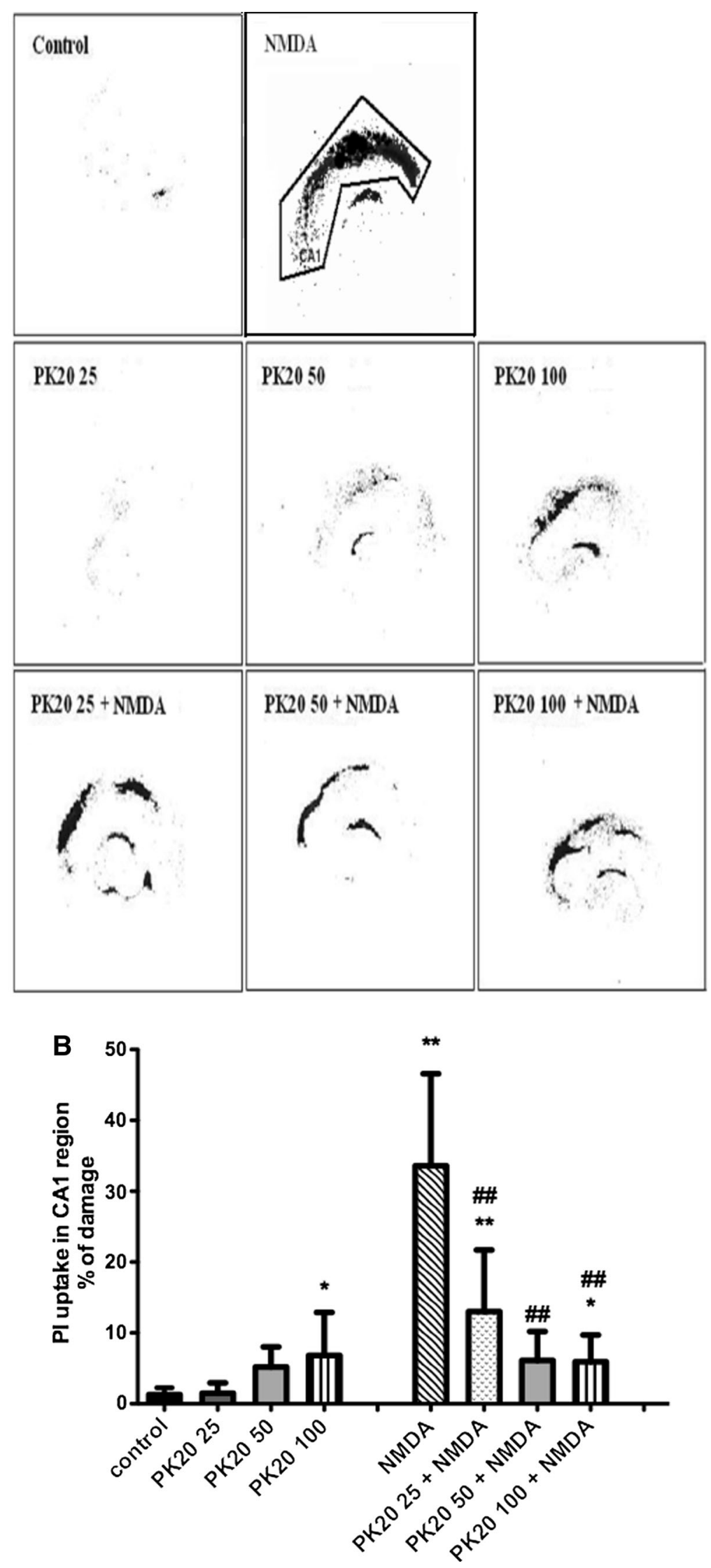


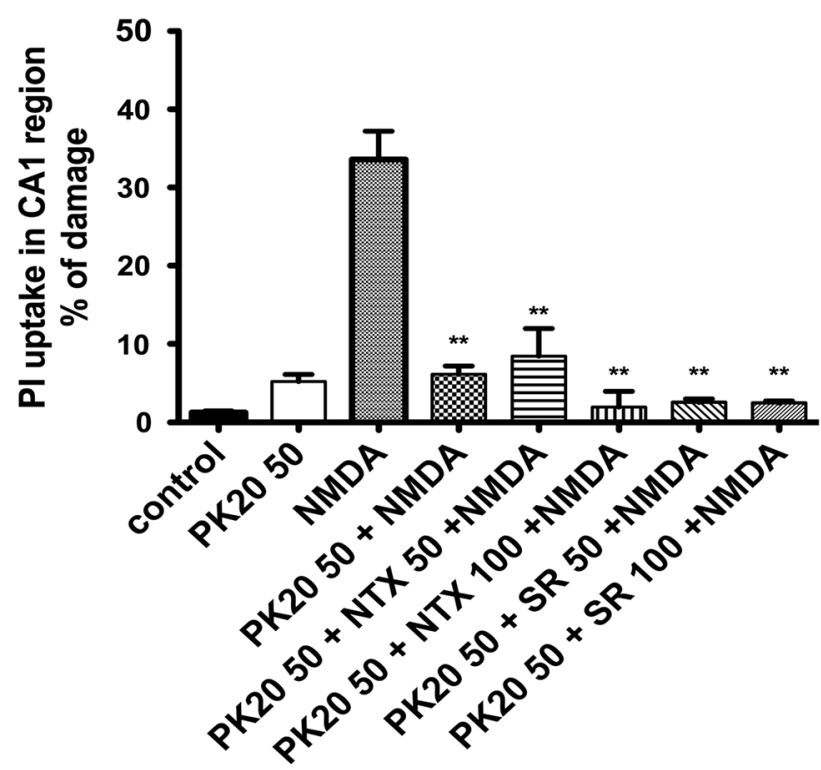

Fig. 4 Neuroprotective effects exerted by a combination of PK20 chimera and a selective antagonist of its each structural pharmacophore in vitro in rat organotypic hippocampal cultures (OHC). Quantitative analysis of cell death of OHC, $24 \mathrm{~h}$ after glutamatergic stress (1 mM NMDA). Hippocampal slices were treated with a constant concentration of PK20 opioid-neurotensin hybrid peptide (50 ng/ml) and with variable concentrations of either (i) selective opioid receptor antagonist (naltrexone, NTX: $50,100 \mathrm{ng} / \mathrm{ml}$ ) or ii) NTS1 neurotensin receptor selective antagonist (SR 48692: 50, $100 \mathrm{ng} / \mathrm{ml}$ ) in the presence of NMDA. The results are expressed as the mean \pm S.D. of propidium iodide (PI) positive cells from at least three independent experiments. ${ }^{*} P<0.0001$ versus NMDA

concentration of PK20 (100 ng/ml) showed a slightly elevated percentage of PI-positive cells, as compared to the control. However, the CA1 damage caused by the highest dose of PK20 differed from that exerted by $1 \mathrm{mM}$ NMDA. The low toxicity related to the peptides enabled further analysis in the presence of NMDA receptor agonists.

In another set of experiments, we found that both concentrations (50 and $100 \mathrm{ng} / \mathrm{ml}$ ) of PK20 and NT almost completely abolished NMDA-induced cell death, making the percentage of PI-positive cells comparable to that of the NMDA-untreated control. For PK20, the lowest concentration of $25 \mathrm{ng} / \mathrm{ml}$, reduced the NMDA cell damage in the CA1 region. These results are very promising, when considering the potential pharmacological applications. Thus, the chemical hybridization of a NT analog together with an opioid pharmacophore eventually produces a similar effect to that observed for NT (Figs. 2b, 3b). Apart from the fact that the neuroprotective activity of either NT or PK20 is almost the same, it seems that this opioid-NT hybrid peptide may be more effective in vivo as it has improved stability against enzymatic degradation, better bioavailability as well as the ability to cross the blood brain barrier (BBB) (Kleczkowska et al. 2010). While the PK20 chimera is characterized by the necessary CNS access
(Kleczkowska et al. 2010), NT as well as the majority of its designed analogs does not penetrate across the blood-brain barrier (Vincent 1995).

Additionally, hybrid structures are designed to counterbalance known undesirable side effects that are intrinsically linked to the parent drug. Opioid treatment can potentially result in nausea (Porreca and Ossipov 2009), constipation (Leppert 2010), characteristic tolerance (Benyamin et al. 2008; Cochin and Kornetsky 1964), and physical dependence (Delander and Takemori 1983). Their use is very controversial and may not be accepted by some patients and therapists. Moreover, another advantage of hybrid structures is that the can be used to effectively target multifaceted diseases and thus may act not only on one disease but on various co-existing conditions. This is very important because many complex pathologies remain inadequately treated by the commonly used principle of "one molecule-one target-one disease" (Decker 2011; Fuji 2011).

In addition, we have found that the partial blockade of PK20 by means of the NTS1 receptor antagonist SR48692, or by naltrexone as an opioid receptor antagonist, did not produce an increased neuroprotective activity (Fig. 4). This, in turn, may suggest that both opioid and NT moieties are similarly involved in PK20-induced neuroprotection and a direct additive relation between both structural elements occurred. Indeed, while testing a pure opioid pharmacophore (data not shown) we found that this element is crucial for the neuroprotective activity exerted by the whole chimeric compound. Importantly, the number of dead cells of a CA1 hippocampal region was comparable to that observed in the control experiment (NMDA/PK20untreated slices). However, this does not appear to fully explain the exact neuroprotective mechanism induced by the chimeric compound.

Although PK20, an opioid-neurotensin hybrid peptide, was found to be a full agonist towards either mu opioid $\left(E_{\max }=149.1 \pm 2.9 \%\right.$ and $\left.\mathrm{EC}_{50}=70.09 \pm 0.08\right)$ or NTS1 neurotensin receptors $\left(E_{\max }=141.3 \pm 3.8 \%\right.$ and $\mathrm{EC}_{50}=66.6 \pm 0.24$ ) (data not published), it is possible that the observed neuroprotective effect is a consequence of activation of other receptors. Likely, NTS2 or even kappa opioid receptor are involved. This, in turn, can result in broadening the spectrum of interactions between compound and receptors other than only opioid and neurotensin receptors. However, to report a precise mechanism of PK20 neuroprotection, further investigations need to be carried out. Of note, neither naltrexone nor SR 48692 exerted toxic effects on hippocampal slices (data not shown).

We also report the involvement of NT in the protection of a hippocampal CA1 region. Interestingly, when considering the results obtained for NT, we demonstrated that NT did not induce any significant cell death in comparison 
to either untreated slices (control) or NMDA-treated cultures. Although our in vitro observations are very interesting, it should be taken into account that endogenous NT was shown to increase glutamate release in the striatum, globus pallidus, frontal cortex, and substantia nigra (Ferraro et al. 2011) implicating the role of NT in conditions, such as stroke or Alzheimer's disease. The fundamental reason for such differences is unknown.

In conclusion, the opioid-NT hybrid peptide PK20 presents neuroprotection against NMDA-mediated excitotoxicity in rat organotypic hippocampal slice cultures. Such neuroprotective properties validate the approach of using chimeric drugs with designed multitarget properties. Moreover, when the examined chimera was tested in the presence of selective opioid or NT receptor antagonists, PK20's neuroprotective activity did not result from either opioid structural elements or the NT pharmacophore.

Acknowledgments This work was supported by a grant from the National Science Centre (2011/03/N/NZ4/02417). We thank the staff of the Laboratory of Advanced Microscopy Techniques of MMRC PAS for technical support. We would like to thank Prof. Steven Ballet for helping us to prepare the manuscript in a more scientific way.

Open Access This article is distributed under the terms of the Creative Commons Attribution 4.0 International License (http://crea tivecommons.org/licenses/by/4.0/), which permits unrestricted use, distribution, and reproduction in any medium, provided you give appropriate credit to the original author(s) and the source, provide a link to the Creative Commons license, and indicate if changes were made.

\section{References}

Antonelli T, Ferraro L, Fuxe K, Finetti S, Fournier J, Tanganelli S, De Mattei M, Tomasini MC (2004) Neurotensin enhances endogenous extracellular glutamate levels in primary cultures of rat cortical neurons: involvement of neurotensin receptor in NMDA induced excitotoxicity. Cereb Cortex 14:466-473

Arundine M, Tymianski M (2004) Molecular mechanisms of glutamate-dependent neurodegeneration in ischemia and traumatic brain injury. Cell Mol Life Sci 61:657-668

Benyamin R, Trescot AM, Datta S, Buenaventura R, Adlaka R, Sehgal N, Glaser SE, Vallejo R (2008) Opioid complications and side effects. Pain Physician 11:S105-S120

Bradfrod HF, Crowder JM, White EJ (1986) Inhibitory actions of opioid compounds on calcium fluxes and neurotransmitter release from mammalian cerebral cortical slices. Br J Pharmacol 88:87-93

Chen TY, Goyagi T, Toung TJ, Kirsch JR, Hurn PD, Koehler RC, Bhardwaj A (2004) Prolonged opportunity for ischemic neuroprotection with selective $\kappa$-opioid receptor agonist in rats. Stroke 35:1180-1185

Chiba T, Nishimoto I, Aiso S, Matsuoka M (2007) Neuroprotection against neurodegenerative diseases: development of a novel hybrid neuroprotective peptide Colivelin. Mol Neurobiol 35:55-84

Cochin J, Kornetsky C (1964) Development and loss of tolerance to morphine in the rat after single and multiple injections. J Pharm Exp Ther 145:1-20
Decker M (2011) Hybrid molecules incorporating natural products: applications in cancer therapy, neurodegenerative disorders and beyond. Curr Med Chem 18:1464-1485

Delander GE, Takemori AE (1983) Spinal antagonism of tolerance and dependence induced by systemically administered morphine. Eur J Pharmacol 94:35-42

Ferraro L, Beggiato S, Tomasini MC, Fuxe K, Tanganelli S, Antonelli $\mathrm{T}$ (2011) Neurotensin regulates cortical glutamate transmission by modulating $N$-methyl-D-aspartate receptor functional activity: an in vivo microdialysis study. J Neurosci Res 89:1618-1626

Fuji H (2011) Twin and triplet drugs in opioid research. Top Curr Chem 299:239-725

Gähwiler BH, Capogna M, Debanne D, McKinney RA, Thompson SM (1997) Organotypic slice cultures: a technique has come of age. Trends Neurosci 20:471-477

Hynd MR, Scott HL, Dodd PR (2004) Glutamate-mediated excitotoxicity and neurodegeneration in Alzheimer's disease. Neurochem Int 45:583-595

Kawalec M, Kowalczyk JE, Beresewicz M, Lipkowski AW, Zablocka B (2011) Neuroprotective potential of biphalin, multireceptor opioid peptide, against excitotoxic injury in hippocampal organotypic culture. Neurochem Res 36:2091-2095

Kleczkowska P, Kosson P, Ballet S, Van den Eynde I, Tsuda Y, Tourwé D, Lipkowski AW (2010) PK20, a new opioid neurotensin hybrid peptide that exhibits central and peripheral antinociceptive effects. Mol Pain 6:86

Kleczkowska P, Lipkowski AW, Tourwé D, Ballet S (2013) Hybrid opioid/non-opioid ligands in pain research. Curr Pharm Des 19:7435-7450

Köhler C, Radesäter AC, Chan-Palay V (1987) Distribution of neurotensin receptors in the primate hippocampal region: a quantitative autoradiographic study in the monkey and the postmortem human brain. Neurosci Lett 76:145-150

Leppert W (2010) The role of opioid receptor antagonists in the treatment of opioid-induced constipation: a review. Adv Ther 27:714-730

Li S, Lei S (2006) Neurotensin facilitates GABA release in rat hippocampus. The FASEB J 20:A243

Liu Y, Li J, Yang J, Ji F, Bu X, Zhang N, Zhang B (2008) Inhibition of PKCgamma membrane translocation mediated morphine preconditioning-induced neuroprotection against oxygen-glucose deprivation in the hippocampus slices of mice. Neurosci Lett 444:87-91

Mark LP, Prost RW, Ulmer JL, Smith MM, Daniels DL, Strottmann JM, Brown WD, Hacein-Bey L (2001) Pictorial review of glutamate excitotoxicity: fundamental concepts of neuroimaging. Am J Neuroradiol 22:1813-1824

Murphy N, Bonner HP, Ward MW, Murphy BM, Prehn JH, Henshall DC (2008) Depletion of 14-3-3 zeta elicits endoplasmic reticulum stress and cell death, and increases vulnerability to kainate-induced in mouse hippocampal cultures. J Neurochem 106:978-988

Narita M, Kuzumaki N, Miyatake M, Sato F, Wachi H, Seyama Y, Suzuki T (2006) Role of $\delta$-opioid receptor function in neurogenesis and neuroprotection. J Neurochem 97:1494-1505

Noraberg J, Poulsen FR, Blaabjerg M, Kristensen BW, Bonde C, Montero M, Meyer M, Gramsbergen JB, Zimmer J (2005) Organotypic hippocampal slice cultures for studies of brain damage, neuroprotection and neurorepair. Curr Drug Targets 4:435-452

Olney JW, Sharpe LG, Feigin RD (1972) Glutamate-induced brain damage in infant primates. J Neuropathol Exp Neural 31:464-488

Pinnock RD (1992) A highly selective kappa-opioid receptor agonist, CI-977, reduces excitatory synaptic potentials in the rat locus coeruleus in vitro. Neurosci 47:87-94

Porreca F, Ossipov MH (2009) Nausea and vomiting side effects with opioid analgesics during treatment of chronic pain: mechanisms, implications, and management options. Pain Med 10:654-662 
Ring A, Tanso R, Noraberg J (2010) The use of organotypic hippocampal slice cultures to evaluate protection by noncompetitive NMDA receptor antagonists against excitotoxicity. ATLA 38:71-82

Stoppini L, Buchs PA, Muller D (1991) A simple method for organotypic cultures of nervous tissue. J Neurosci Methods 37:173-182

Vaccarino AL, Olson GA, Olson RD, Kastin AJ (1999) Endogenous opiates; 1998. Peptides 20:1527-1574

Vincent JP (1995) Neurotensin receptors: binding properties, transduction pathways, and structure. Cell Mol Neurobiol 15:501-512

Yang Y, Xia X, Zhang Y, Wang Q, Li L, Luo G, Xia Y (2009) $\delta$ opioid receptor activation attenuates oxidative injury in the ischemic rat brain. BMC Biol 7:55-64
Yang L, Shah K, Wang H, Karamyan VT, Abbruscato TJ (2011a) Characterization of neuroprotective effects of biphalin, an opioid receptor agonist, in a model of focal brain ischemia. J Pharmacol Exp Ther 339:499-508

Yang L, Wang H, Shah K, Karamyan VT, Abbruscato TJ (2011b) Opioid receptor agonists reduce brain edema in stroke. Brain Res 1383:307-316

Zhang J, Haddad GG, Xia Y (2000) $\delta$-, but not $\mu$ - and $\kappa$-, opioid receptor activation protects neocortical neurons from glutamateinduced excitotoxic injury. Brain Res 885:143-153 